v. $11, n .1$

Vitória-ES, Jan.-Feb. 2014

p. $48-68 \quad$ ISSN 1808-2386 DOI: http://dx.doi.org/10.15728/bbr.2014.11.1.3

\title{
The financial value of human capital and the challenge of retaining it
}

\author{
Marta Corrêa Dalbem ${ }^{\dagger}$ \\ UNIGRANRIO \\ Carlos de Lamare Bastian-Pinto ${ }^{\Omega}$ \\ IBMEC \\ Alexandre Mattos de Andrade ${ }^{¥}$ \\ UFRJ
}

\begin{abstract}
:
Determining the value of companies based on human capital is a growing challenge in an economy increasingly based on knowledge and services. Such companies also depend on the contribution of key people to generate value, especially at certain phases of their development. Based on a case study of an engineering design firm (Firm), this article details a method that can be replicated to determine the value of other companies in the service sector. We also propose a financial method to support decisions on sharing that value - and how to do so - among the key people, to compensate them in line with the importance of their contributions. Finally, we point out the difficulties of this process and the variables that must be monitored by companies to reach their objectives of creating value and retaining talents.
\end{abstract}

Keywords: Economic value. Human capital, Intellectual capital. Intangibles.

Received on May 08, 2012; reviewed on July 19, 2012; accepted on July 24, 2012; disclosed on March $12,2014$.

* Author for correspondence:

${ }^{\dagger}$.PhD in Finance from PUC-Rio. Institution: Assistant Professor at UNIGRANRIO.

Address: Rua da Lapa, 86, $9^{\circ}$. Andar, Rio de Janeiro - RJ - Brazil

E-mail: marta.dalbem@unigranrio.br; martadalbem@hotmail.com

Telephone: (21) 2531-8804
${ }^{\Omega} \mathrm{PhD}$ in Finance from PUC-Rio.

Institution: Assistant professor at IBMEC.

Address:Av. Presidente Wilson, 118, sala 1104,

Rio de Janeiro - RJ - Brazil

E-mail: carlosbastian@ibmecrj.br

Telephone: (21) 4503-4146
${ }^{\sharp}$ MSc from Rio de Janeiro Federal University

Address: Rua: Desembargador Alfredo Russel, 70, 401, Leblon

Rio de Janeiro - RJ - Brazil

E-mail: almattan@gmail.com

Telephone: (21) 9394-0900

Note from the Editor: This article was accepted by Bruno Funchal.

(cc) $\mathrm{Br}$

This article has a Creative Commons License - Attribution 3.0 Not Adapted. 


\section{INTRODUCTION}

he service sector today accounts for about two-thirds of Brazil's GDP. In this

sector, companies with high intellectual content stand out, such as engineering and law firms, design and advertising agencies, among others. Most companies focused on services are small to medium in size and are often involved in mergers and acquisitions. A particular challenge faced by these firms is to retain talents and adequately compensating their internal and external specialists (consultants). How can such companies be valued? How should the wealth generated be divided among the participants, based on their contribution to the company's value?

The literature on the valuation of intangibles is extensive, but few studies have put the theoretical concepts into empirical practice. There are also few works considering sectors in which the majority of firms are not publicly traded, have a relatively small number of employees and depend on key people to assure profits and longevity. Such companies are particularly reliant on employees as well as outside consultants with specific knowledge. In this article we try to fill in this gap, describing the process of valuing a Brazilian company engaged in engineering projects (Firm), focusing on the method used and how the varied difficulties encountered in the process of evaluating the intellectual capacities/intangibles were overcome. We also address the issue of how to remunerate key people based on their capacity to generate value, with the aim of retaining them.

The article is organized into five sections including this introduction. The second section contains a literature review; the third describes the Firm and its main value drivers, the valuation method and assumptions used; the fourth presents a rationale on how to compensate key personnel; and the fifth sets out the conclusions and suggestions for future research.

\section{LITERATURE REVIEW}

According to Bouteiller \& Karyotis (2010), intangibles are generally the result of a company's past activities and have three main characteristics: they are non-physical assets, they can produce future financial results and they are protected legally or by de facto rights held by the firm, enabling it to generate cash flow. Intangible assets cover a wide range of capabilities developed by the company, including brands, knowledge from a trained workforce, distribution and operational contracts, strong relationships with customers and suppliers, good relations with the community, contracts that serve as barriers to competitors, and reputation, among others. 
Boutellier \& Karyotis (2010) add that intellectual capital basically involves three dimensions $\backslash$; human (knowledge and ability to execute tasks); structural (organization of processes, teamwork); and relational (relationship with customers and suppliers). This classification is similar to those used by Kayo (2002), Sveiby (1997, cited in Kayo et al., 2006), Kristandal \& Bontis (2007) and Lima \& Carmona (2010, 2011).

Authors such as Stewart (1997) and Klein \& Prusack (1994), in discussing human capital, clarify that for the tacit knowledge of employees and external specialists to be converted into an asset, some type of formalization and ordering/organization is necessary to allow that knowledge to be protected and monetized. Sullivan (2000) also points out that such organization and formalization of knowledge will only have value when aligned with the vision and strategy of the company. In other words, the company must be able to make that knowledge generate results.

Boutellier \& Karyotis (2010) review the literature on methods to value intangible assets, including methods that compare the market value against the book value or replacement value of the intangible assets (market-to-book and Tobin's Q, respectively), or methods that estimate the exceeding cash flow a company is able to generate in comparison to its competitors, segregating how much of this superior performance results from tangible and intangible assets. In all these methods, the generation of value also depends on the firm's tangible assets, and segregating that contribution poses an additional difficulty in pricing the intangible assets. The methods are generally flawed and incomplete, and can only be applied to companies with shares traded in the market. This winds up excluding a large portion of Brazilian service companies.

The same difficulty exists in methods based on multiples, which use as a reference recent transactions or licensing agreements involving similar assets. Even when it is possible to identify those transactions and the amounts involved, doubt remains as to how similar the reference assets are to those targeted for valuation. As pointed out by Kayo et al. (2006), a fundamental trait of all intangible assets is their singularity and thus unique ability to generate competitive advantages and abnormal returns in relation to the market. This makes valuation of intangibles based on multiples a dicey proposition. Nevertheless, multiples continue being used for the valuation of companies, such as in Deutscher (2005), who uses a combination of methods to converge to the fair value of firms.

Reilly \& Schweihs (1998) try to estimate the replacement cost of an intangible asset, i.e., the cost that would be necessary to develop that intellectual capital, including the costs 
already incurred in personnel, systems and everything else necessary to develop the intellectual capital. Even though such costs are easy to obtain from the accounting books, it is evident that using this method for valuation runs up against the impossibility of connecting costs with the persons who really generated the knowledge. Nor can it be forgotten that certain people are not easily replaced, particularly in small firms. As pointed out by Kayo et al. (2006, p. 81), in Brazil there is an additional difficulty, because unlike in the United States, the accounting of $R \& D$ expenditures or other intangibles is very hard to identify ${ }^{1}$.

There is a consensus in many of the mentioned works that the best way is to try to estimate the economic benefits obtained by the company, segregating them to the extent possible into those derived from tangible and intangible assets, and bringing those benefits to present value by applying a discount rate that reflects the inherent risk of the business. According to Deutscher (2005), this "good old cash flow" method is the most appropriate. Damodaran (2009) also uses discounted cash flow, while noting the challenge of estimating future cash flows generated by intangible assets.

The method proposed by Lev \& Mintz (1999) seeks to separate the value generated by intangibles from that generated by tangible assets by simply deducting the cash flow generated on average by tangible and financial assets from the firm's total cash flows, obtaining a "normalized" cash flow, which is then brought to present value by applying a suitable discount rate. That discount rate can be similar to the rate of return required by the market for companies that are intensive in intangible capital, such as biotech and software companies, among others.

Lev (2001, cited in Kayo et al., 2006) argues that the risk of intangible assets is substantially higher than that of tangible assets, so the discount rate should be commensurately higher. On the other hand, Boutellier \& Karyotis (2010) note that certain intangible assets open the company to new future options, such as the option to expand in a determined market or even interrupt $R \& D$ investments if the scenario turns unfavorable. These options/flexibilities generate additional value that can be priced best by the real options method, as detailed in Trigeorgis (1993), Copeland \& Antikarov (2003) and Amram \& Kulatilaka (1999). The high market value attributed to companies focused on R\&D, such as

\footnotetext{
${ }^{1}$ This situation has become less vexing for researchers since the reform of Brazil's accounting standards, effective in 2009, bringing them into convergence with international standards (IFRS), which included the creation of a new account to cover intangible assets in the financial statements.
} 
software and pharmaceutical companies, demonstrates that the flexibilities inherent in intangible assets far outweigh the higher risks associated with knowledge-based activities.

Deutscher (2005) further stresses that the value of an intangible good does not depend on the asset itself, but also, and often more significantly, on how that intangible asset fits into the buyer's strategy. The author gives the example of the privatization of Banespa in Brazil, in which Spain's Santander priced the company nearly four times higher than competing Brazilian banks in the bidding, because of its value as a platform for fast entry in the Brazilian market, with options for expansion.

Studies such as Nelson (1982, cited in Boutellier and Karyotis, 2010) comment on the possible obsolescence of intangible assets, which just like other assets can have a limited useful lifetime or can depreciate due to the actions of rivals. According to Deng, Lev \& Narin (1999), the shorter the cycle of new patents, the better the performance of firms in market value, i.e., in industries with higher frequency of innovation, the value of firms tends to be higher. The maintenance or growth of the value of a business depends, in this case, on its capacity to generate innovations or new products to counterbalance fading products. That capacity is hence a valuable intangible asset.

Reilly \& Schweins (1999) point out that, eventually, the capacity to produce financial results determines the economic value of an intangible asset. Sullivan (2000), in defining intellectual capital as knowledge that can be converted into profit, also stresses this economic foundation, measureable by the discounted cash flow or real options method. We chose the discounted cash flow method for application in this work.

\section{METHODOLOGY}

Although the literature is rich in ideas on how to value intangibles, few authors have tried to actually apply them in the solution of real cases. We aim to contribute in this respect, by describing the process of appraising an engineering design firm, illustrating what intellectual/intangible capabilities exist in knowledge-based companies and how those capabilities generate financial results. Besides this, we propose a rationale on how to estimate the financial value aggregated by key people, to support decisions on how to compensate them fairly.

To preserve confidentiality, that engineering design company will be referred to as the Firm. The Firm is not only intensive in intellectual/human capital, it also currently needs to value this capital. Controlling partners (henceforth called Shareholders) currently deem it as 
important to take the value of this human capital into account when remunerating the key people (from now on called Specialists). These Specialists are both employees and external consultants and as a group detain the major part of the intangible capital necessary for the Firm's success.

Shareholders are aware of the difficulty of incorporating in the firm's assets the intellectual capital that is fundamental for generating its revenue streams, because as pointed out by Lev (2001, cited in Kayo et al., 2006), this capital is very volatile and risky. Nelson (1982, cited in Boutellier; Karyotis, 2010) also stresses that this capital is vulnerable to obsolescence, so it requires special attention. So the Shareholders are concerned to develop ways to compensate the holders of this intangible capital, both in situations where the specialists have sole possession and also when that knowledge has been disseminated in the firm. In the latter case, a fair remuneration encourages the Specialists to transfer their intellectual capital to the firm.

\subsection{THE FIRM}

The Firm was founded in the 1970s for the purpose of supplying specialized engineering designs to clients in the public and private sector. It has since grown organically and also by aggregating new types of services (hereafter called Products) to its portfolio. In 2005 it took a significant step forward with the introduction of a new Product. Other new Products have also become significant money earners since 2006. When a client signs a new contract with the Firm, it can involve one or more Products. Each Product is tied to various contracts with diverse clients.

Although it initially grew by serving clients in the private sector, the Firm now obtains about two-thirds of its gross revenue from the public sector or companies/organizations linked to the public sector. In this segment it has established the status of recognized specialization, an important intangible asset that gives it a huge competitive advantage because it allows contracting certain products with public-sector entities without going through a tendering process. Recognized specialization status is the result of the acknowledged capability of a company in a determined field of knowledge or endeavor, so that it is considered to offer unique products and/or services, superior to those of any competitor. This recognition is one more facet of the Firm's human capital, more specifically of its relational capital, as discussed in section 3.3. Therefore, the benefits of the recognized specialization are reflected in the expected future cash flows of each of the Firm's Products that fall in this category, and its 
value should also be shared with those responsible for developing and maintaining this competitive advantage.

The Firm's contracts generally have tenors of under six months, so there is a constant need to find new clients/contracts, a common situation for companies in the service sector. The introduction of new Products not only allows adding new clients, but also exploring other market niches among traditional clients. This has been responsible for substantial growth in revenues in recent years, as shown in Figure 1.

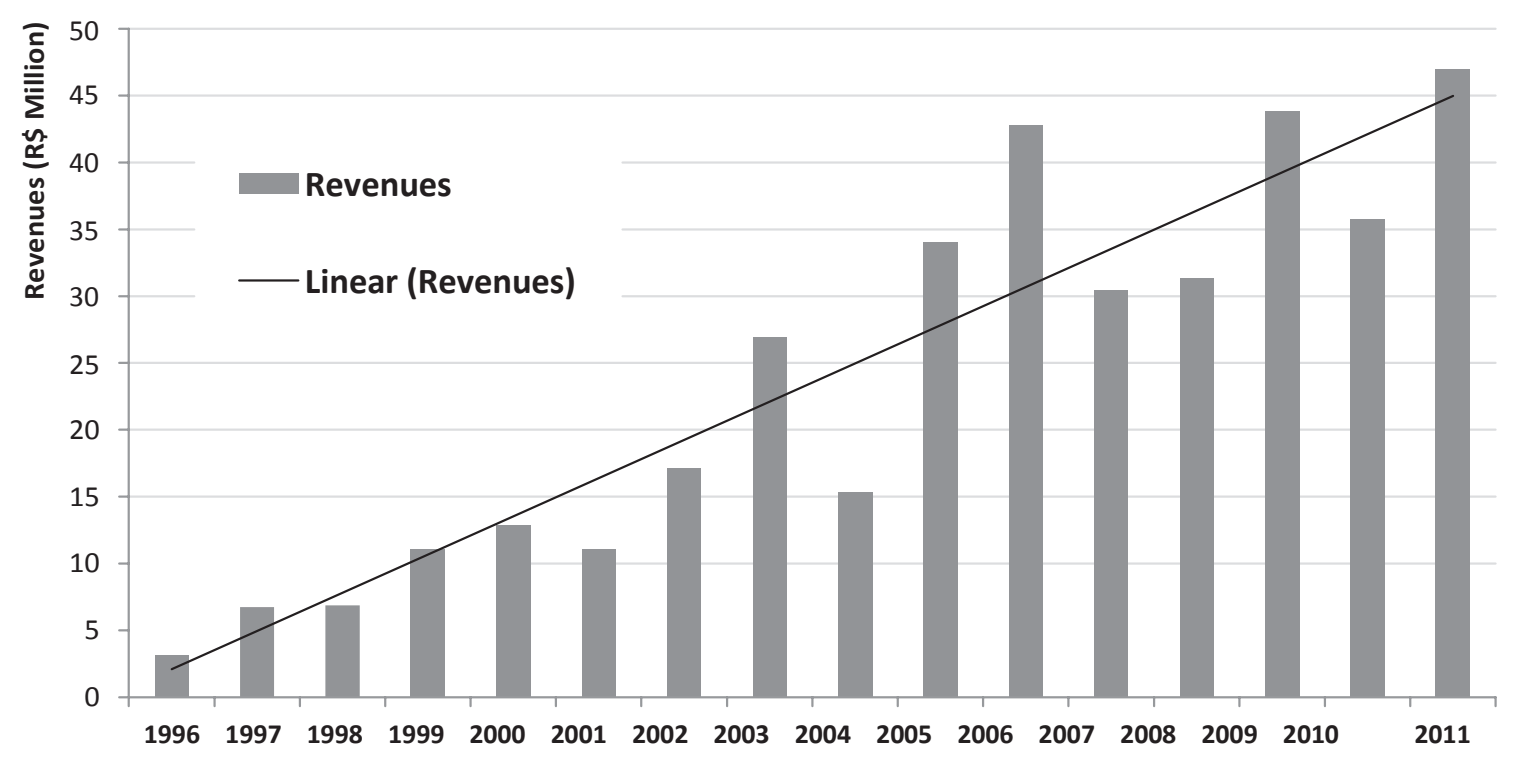

Figure 1: Evolution of the Firm's revenues, in values as of December 2011

The Specialists originate contracts, introduce new Products or bring new clients to the Firm, and thus are important to its longevity. They are remunerated for the time worked and also receive a commission on the profit forecast for each contract, at a percentage negotiated in advance, paid whether or not the profit materializes. To summarize, the Specialists are compensated based on the projected rather than realized profit. This is a common practice in service companies that contract employees and consultants. The clients' default rate has traditionally been very low, so that nearly all billings are paid, although occasionally with some delay. The Specialists are therefore not subject to clients' default or volatility of profits.

The average profit margin in the period from 2006 to 2011 was $20 \%$, below the $25 \%$ used as target in the contracts and as a reference for compensating the Specialists. There was considerable volatility in the period, with the margin ranging from $-7 \%$ to $38 \%$. The Firm's managers and the Specialists participate together in the budgeting and pricing of each 
contract, as well as in defining the costs to be incurred during performance of each contract. Therefore, both the Firm and the Specialists contribute to and have responsibility for this volatility, but the Firm absorbs the bottom-line impacts.

Table 1 shows the relative importance of each Product in generating cash flow and demonstrates that such stakes vary a lot. This is common among service companies, so projections are a challenging task. We held about ten meetings with two executives of the Firm and a representative of the group of Shareholders to define the assumptions to be used in the projections. Despite the limited data available broken down by Product - only five years -,the group involved in the discussion had extensive experience in the Firm, which facilitated the brainstorming on the future perspectives of each Product. At the end, the Shareholders and executives agreed to use the average participation over the past five years as a benchmark for the relative importance of each Product in future cash flows.

Table 1: Relative Importance of the Products (2007-2011)

\begin{tabular}{|l|l|l|l|l|l|l|}
\hline Participation in the Free Cash Flow to Shareholders - (\%of FCFE) \\
\hline Products & $\mathbf{2 0 0 7}$ & $\mathbf{2 0 0 8}$ & $\mathbf{2 0 0 8}$ & $\mathbf{2 0 1 0}$ & $\mathbf{2 0 1 1}$ & $\begin{array}{l}\text { Mean/ } \\
\text { Projection }\end{array}$ \\
\hline Product 1 & $22.0 \%$ & $11.7 \%$ & $2.9 \%$ & $8.4 \%$ & $2.8 \%$ & $9.6 \%$ \\
Product 2 & $34.2 \%$ & $68.1 \%$ & $47.0 \%$ & $52.7 \%$ & $20.0 \%$ & $44.4 \%$ \\
Product 3 & $10.5 \%$ & $4.8 \%$ & $3.8 \%$ & $0.0 \%$ & $4.6 \%$ & $4.7 \%$ \\
Product 4 & $27.6 \%$ & $13.4 \%$ & $38.3 \%$ & $34.1 \%$ & $15.0 \%$ & $25.7 \%$ \\
Product 5 & $5.7 \%$ & $2.0 \%$ & $3.0 \%$ & $4.8 \%$ & $19.1 \%$ & $6.9 \%$ \\
Product 6 & $0.0 \%$ & $0.0 \%$ & $5.0 \%$ & $0.0 \%$ & $38.5 \%$ & $8.7 \%$ \\
\hline
\end{tabular}

Among the risks facing the Firm and its shareholders, which can also affect the Firm's value, the following were considered the most relevant:

- $\quad$ risk of not obtaining new contracts/clients

- risk of incorrectly pricing contracts, by underestimating costs

- risk of client default

- risk that the service will not satisfy the client

- $\quad$ risk of losing key people

- technological risks that can result in loss of information

- risks of tax fines and labor lawsuits 
If those risks were perceived as differentiated per Product (in this case determinable by the method proposed by Hubbard, 2010), a different discount rate could be used for each Product. In this exercise, we could even have used different volatilities and rates, depending on the content of each dimension of intangible capital in each Product. However, executives and Shareholders indicated there are no significant differences regarding these aspects.

The tangible capital is very small. The Firm leases office space, so its main tangible asset is its IT equipment, with an irrelevant value in comparison with the intangible capital. Therefore, the questions raised by Lev (2001) and Lev \& Mintz (1999), discussed in section 2, were not taken in to account in the Firm's valuation.

\subsection{INTANGIBLE CAPITAL OF THE FIRM}

As stated, the Firm provides services involving engineering designs, and its capital is almost entirely formed of intangibles. The analysis of the past cash flow generation (free cash flow to the Shareholders), which served as the basis for projections, was performed for each Product, as shown in Table 1, and was based on a short period-2007-2011—during which there is greater detail on the performance of each Product/contract.

There are situations where the knowledge on how to carry out the work is nearly all held by the Specialists, who also originate the contracts because of their professional network. In such cases, the Firm only provides logistic/legal/administrative support, so an important portion of the intangible capital does not belong to the Firm. In such cases, the Specialist can take the clients and knowledge to another company, along with the Product's future cash flows.

At the other extreme, there are situations where the knowledge is already completely disseminated internally, to the point where the Firm alone can originate new business and carry out the work with little or no interference from the Specialist, who most likely permitted or even promoted the dissemination of knowledge within the Firm. In this situation, it makes sense to grant the Specialist an additional remuneration or even an equity stake in the Firm.

Between these two extremes is a grey area that requires analysis of how much each Product - and its capacity to generate cash - is indeed the property of the Firm. In these situations, we used the taxonomy proposed by Kristandal \& Bontis (2007) and Lima \& Carmona (2010), but adapted it to the specific case of the Firm: we analyzed the intangible capital related to each Product in light of its relational, intellectual and structural dimensions, identifying which of these dimensions are already owned by the Firm. 


\subsubsection{Relational Capital}

The relational capital reflects the strength of the relationship of the Firm with the other parties that are important for its success. In practical terms, it refers to the capability to originate new contracts and bring in new clients - either thanks to its network of contacts, or the reputation of the Firm or the Specialist involved in originating the contract. The relational capital also includes the ability to call on a network of collaborators to help perform the contract (e.g., consultants/Specialists or others who facilitate access to information). When this is due to the Firm's reputation, capillarity because of other similar contracts, client loyalty, word of mouth, or also because the Firm enjoys recognized specialization status, the relational capital belongs to the Firm. If the intervention of a Specialist is necessary, then the relational capital has not yet been appropriated by the Firm.

\subsubsection{Intellectual Capital}

The intellectual capital refers to the value aggregated to the Firm by the knowledge about the client and/or the sector where it operates, the technical/theoretical/practical knowledge, the capacity to develop new Products or adjust existing ones to the needs of clients, the ability to learn, the ability to perform contracts within or below the forecasted cost, the capacity to deliver the required quality, the mastery of methodologies. When the Firm detains these capabilities, the value associated with them belongs to the Firm.

\subsubsection{Structural Capital}

The structural capital is connected to the daily routines of the Firm, i.e., its good management practices and internal controls, not only involving the financial and progress monitoring of contracts monitoring, but also the required information and logistic controls, to the point of not requiring the participation of specific persons in those tasks. It also involves a good organizational climate and team spirit.

\subsection{METHODOLOGY UTILIZED TO VALUE THE FIRM}

The valuation of the Firm was based on the discounted cash flow method, according to the assumptions detailed next and segregating the cash flow generation by Product. The discounted cash flow (DCF) method starts with a projection of cash inflows and outflows in future years, seeking to infer the net cash flow Shareholders will obtain at the end of each year. The free cash flows to the Shareholders are brought to present value at the base date (December 2011) using a discount rate considered sufficient to remunerate the inherent risk of the business, while preserving consistency with the return on other investments available in 
the market. We implemented this approach retrospectively for the present values from 1995 to 2010 and then projected the results from 2011 to 2020.

\subsubsection{Discount Rate}

According to financial theory, the higher the risk, the greater will be the return demanded by investors. The broadest concept of risk considers the beneficial effect of diversification, i.e., that a portion of the risk of a determined business can be eliminated without cost simply by portfolio diversification. On the other hand, the risk that remains, even after diversification, must be remunerated by a discount rate which makes economic sense when compared to alternative investments available in the market, including those considered risk free. There are various academically accepted models, of which the most widely used is the capital asset pricing model (CAPM), which we applied in this work.

Considering a market in which a highly diversified portfolio generates a return $\mathrm{Rm}$ to an investor and a risk-free asset generates a return $R f$, the CAPM suggests that the return required by the shareholders of a determined company should be:

$K e=R f-\beta(R m-R f)$, where $\beta$ is a measure of covariance that aims to ascertain the sensitivity of the business return to the return of the market as a whole, both referenced to the risk-free asset's return, $R f$.

In valuing the Firm, we considered the following parameters: $R f=12.0 \%$ per year in nominal terms (similar to the yield of NTN-F $F^{2}$ with maturity in January 2021 ); $R m=19.1 \%$ per year (equivalent to the mean geometric growth of the Ibovespa in 7-year periods since 1994); and sectorial $\beta=0.80$, a value near the average $\beta$ of the service sector in the United States that is closer to the Firm (source: http://pages.stern.nyu.edu/ adamodar). We did not find any listed corporations in Brazil with characteristics similar to those of the Firm that could have served as references to estimate $\beta$. Even in the American market it was hard to identify companies with similar business models, because they also obtain a relevant part of their revenues from operations in other segments. Therefore, sectorial $\beta=0.80$ has a series of limitations. Of particular note is the use of a parameter related to the American market, leading to two alternatives: either consider the other parameters $(R m, R f)$ for the American market as well, adding the Brazil risk premium to the calculation of $\mathrm{Ke}^{3}$; or assume that Brazilian companies in the sector have a similar diversifiable risk in comparison with a

\footnotetext{
${ }^{2}$ NTN-F means National Treasury Notes, series F, issued by the Brazilian Treasury.

${ }^{3}$ This model is known as the Country Spread Model, or Global CAPM Model, as detailed in Mariscal \& Lee (1993).
} 
diversified portfolio of Brazilian assets. We preferred the second alternative, based on the fact that there are various sectors in which this equivalence between the $\beta \mathrm{s}$ in the United States and Brazil are observable (e.g., electric power sector) and also because against the backdrop of the 2008 financial crisis, the concept of country risk for purposes of projection to future years is fragile and difficult to endorse empirically, given the continuing effects of this crisis and the short history of this structural break.

Therefore, based on the parameters described above, we reached a nominal discount rate of $17.7 \%$ per year which, assuming annual inflation of $5 \%$, produced a real discount rate of about $12 \%$ per annum. We used this to bring the projected free cash flows to the Shareholders to present value, always in terms of purchasing power of December 2011.

The literature contains alternative models to the CAPM that result in a higher discount rate for valuation of small companies, as is the Firm's case. Titman \& Martin (2011: 122-123) cite as an example the model adopted by Ibbotson Associates, which attributes an additional risk premium of $4.01 \%$ to companies with market value under US\$ 331 million, or the threefactor model of Fama and French, which also tries to capture an additional risk premium applicable to companies with lower market value. Damodaran (2010: 31-34) reports some empirical studies that try to identify this risk premium for small companies, not always with conclusive results. Damodaran also notes that one problem of adopting an additional risk premium when valuing small companies is that this simplified approach can cause analysts to forgo questioning which factors really make these companies riskier.

Therefore, in valuing the Firm, we adopted the discount rate of 12\% per year indicated by the CAPM, without an additional risk premium. However, the Firm's undeniable higher risk, not only because of its small size, but also due to its dependence on intellectual capital, was taken into account by formulating three possible future scenarios, as described in sections 3.3.2 to 3.3.4.

The discount rate of $12 \%$ p.y., the assumptions adopted for the three future scenarios and the definition of the probabilities of occurrence of those scenarios were discussed in the working meetings with the executives and representative of the Shareholders, and were endorsed by them.

\subsubsection{Scenario 1/Valuation 1: Growth}

We tried to verify the causality between GDP growth and other macroeconomic variables on the Firm's revenues, but the improvement in explanatory power was negligible, 
so to the benefit of parsimony we opted to use a simple regression of the Firm's annual revenues in the period from 1996 to 2011, as a reference for this growth scenario. We therefore assumed in this Scenario 1 that the Firm's revenue will grow by approximately R $\$ 3$ million/year in the next 10 years, a number obtained by simple linear regression, as illustrated in Figure 1. We maintained the historical average profit margin to calculate the future cash flow from each Product. As of 2021, we considered a 3\% real yearly growth of free cash flows to the Shareholders, in perpetuity.

Projections relied on simplified assumptions and a limited method, given the short data history, but these limitations are common even in the valuation of large listed corporations, and will most likely be faced in other valuations of companies in the service sector.

Scenario 1 (optimistic) assumes that the Firm develops a team able to take the place of the current key people and also generates a large enough portfolio of clients/contracts and a strong enough brand to make it resilient to economic squalls and changes in governments. Although in the past the Firm was able to maintain that cash flow growth (or even surpass it), perpetuating this capability is more probable if the Firm becomes large enough not to suffer from the departure of specific people. Besides this, personal relationships with the clients' personnel — not so fundamental if the Firm is among the largest in the sector — are still relevant to generate new business opportunities.

\subsubsection{Scenario 2/ Valuation 2: Business as usual}

Here we assume that in the future the Firm will maintain the average revenue and generation of cash flow observed since 2005-2006, when it reached a new level after the introduction of new Products. In this scenario, the Firm will only be able to replace obsolete Products and the new clients attracted will only offset the loss or exhaustion of opportunities with current clients. This scenario still requires efforts to originate new contracts and the ability to replace any strategic people who leave the fold, in perpetuity.

\subsubsection{Scenario 3 / Valuation 3: Decline}

Scenario 3 (pessimistic) envisions a situation in which the Firm loses some key personnel, and the remaining team members are not able to bring in substantial new contracts or win over clients with the same intensity as in the recent past. It is a scenario of deteriorating structure in which the Firm is sill highly dependent on specific people (in the Firm and within clients) for whom it cannot find suitable successors. There are strategic people among the Shareholders themselves whose absence from the daily routine could contribute to this type of scenario. This scenario also reflects the risk of obsolescence 
described by authors such as Nelson (1982), so we assumed revenues to decline from 2011 onward, until the Firm goes out of business in 2021.

\subsubsection{Weighted scenario}

The model allows weighting the chances that each of these three scenarios will materialize. In the valuation study, we assumed that Scenarios 1 and 2 have respective likelihoods of $50 \%$ and $40 \%$ while the probability of Scenario 3 is $10 \%$. The expected value of the Firm is thus the result of weighting the values obtained in each scenario by the respective probabilities of occurrence, defined in the brainstorming meetings with the executives and Shareholders of the Firm. Those meetings were important to reflect on the additional risks faced by the Firm, because of its dependence on key people and its current stage of development.

Figure 2 shows the value of the Firm in the three different scenarios and also illustrates the final value obtained in the Weighted Scenario, which is $\mathrm{R} \$ 34.7$ million.

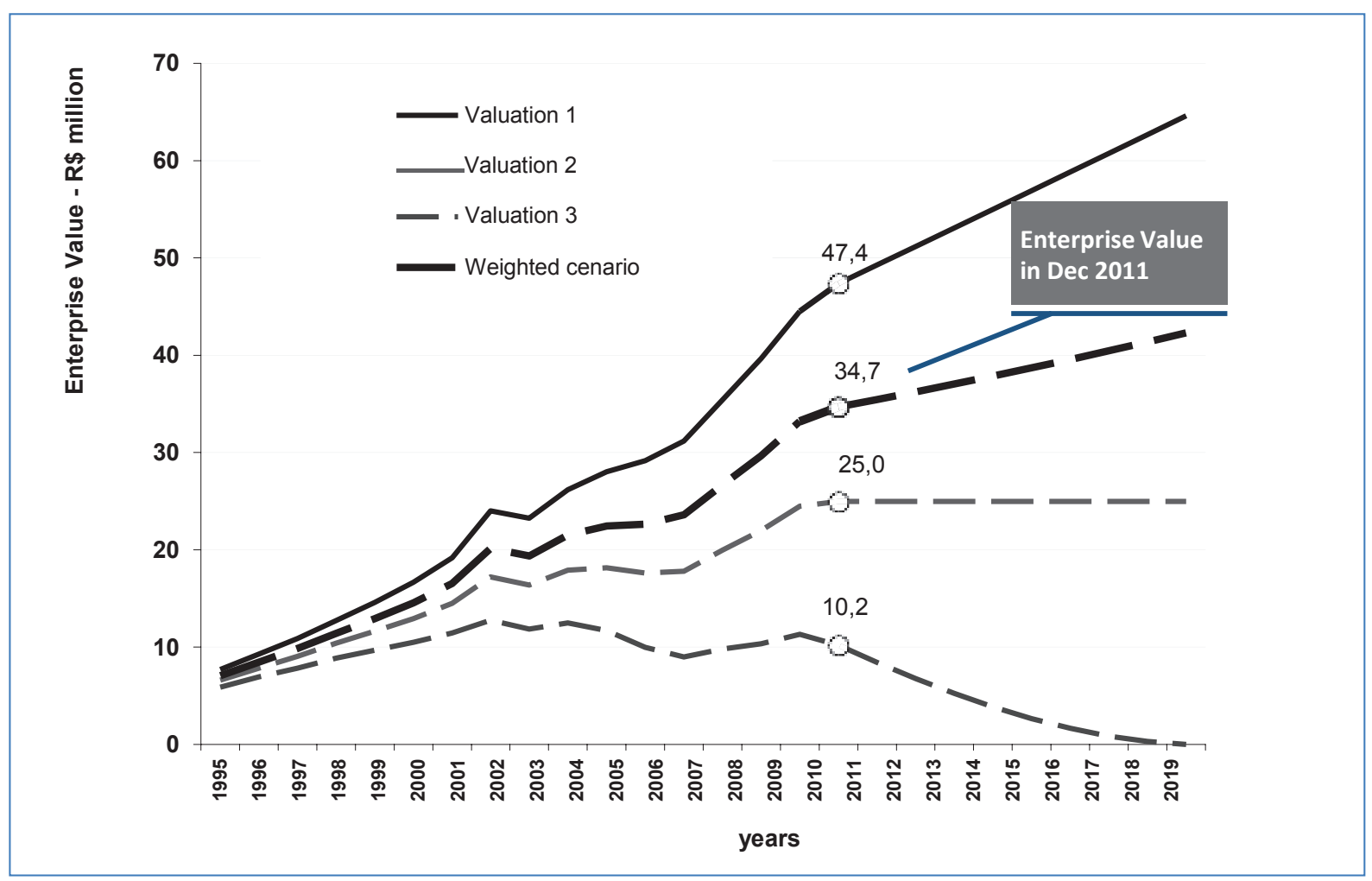

Figure 2: Value of the Firm as of December 2011 (circular points)

A way to analyze the relative importance of each Product during the Firm's history was to bring to present value the future cash flows of each Product, for each year of its history. The values on dates prior to January 2012 do not reflect what would have been considered the actual value of the Firm in each year, because they reflect post-facto values, i.e., they consider the realization of cash flow observed through the end of 2011. Nevertheless, this analysis was 
considered useful by the Shareholders to assess the relative importance of each Specialist.

Figure 3 depicts this analysis for each Product and year, in the Weighted Scenario.

In past years Brazil's real interest rates were much higher than at this writing. Therefore, in estimating how the value increased over the years because of the introduction of new Products, we used decreasing discount rates, falling smoothly from 24\% p.y. in 1995 to $12 \%$ in 2011 and onwards.

The choice of probabilities is key to value the Firm. It was necessary to have a series of discussions with the Firm's executives and Shareholders as well as to conduct sensitivity analyses to these and other assumptions, such as cash flow growth rates, net margins per Product and each Product's stake in revenues. We adjusted these assumptions, within the limits considered possible by the executives and Shareholders, to reach the Weighted Scenario considered most reasonable.

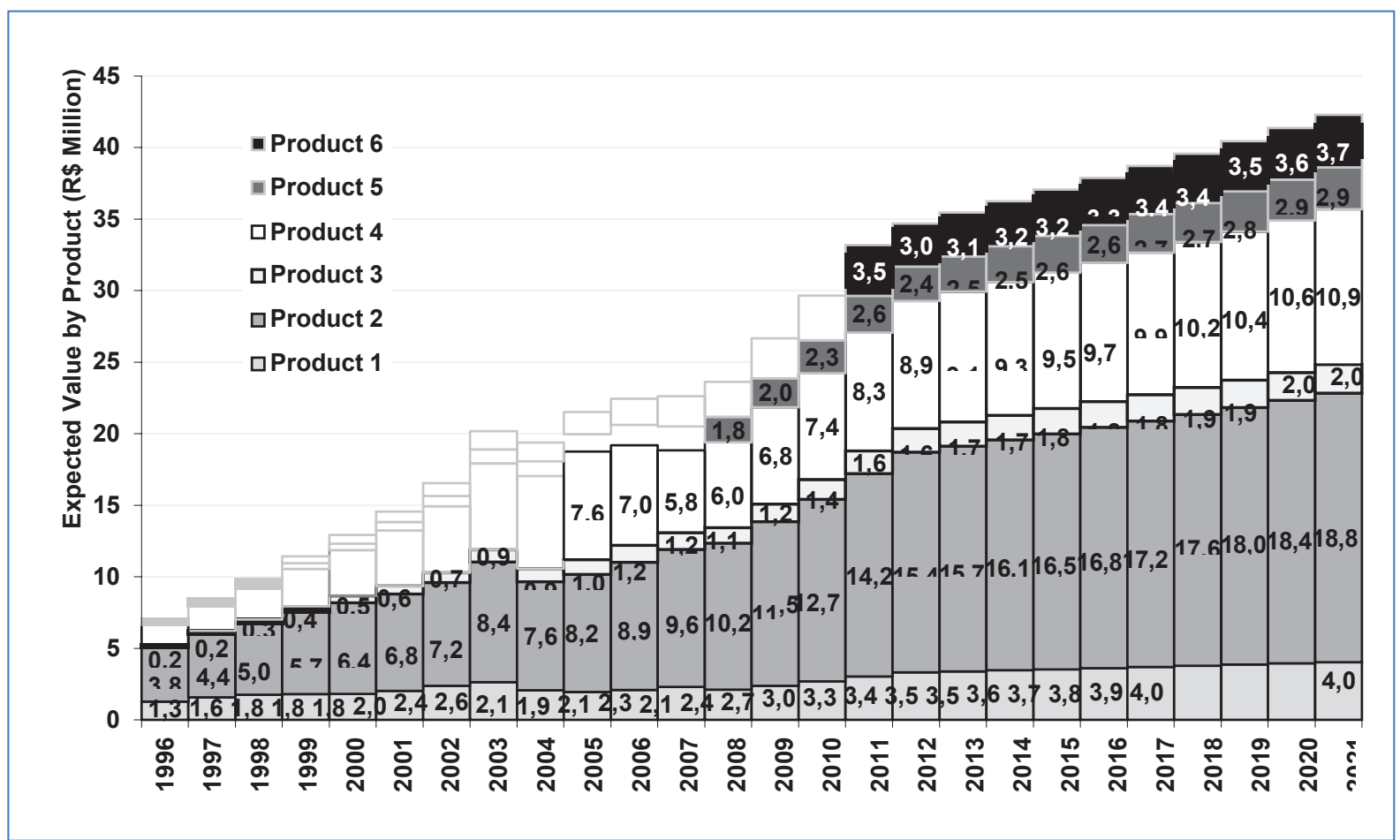

Figure 3: Decomposition of the value per Product in the Weighted Scenario

\section{HOW TO COMPENSATE SPECIALISTS}

The previous sections showed the approach used to overcome the challenge of projecting the future ability to convert intangible capital into cash flow. An even greater challenge, however, is to define the persons who contributed/are contributing to build this capital, and to what extent. This analysis was based on December 2011 value of each Product in the Weighted Scenario, and also on the stage of appropriation of the knowledge by the Firm, in each Product. 
According to the typology adopted for the components of the Firm's intangible capital in section 3, it is clear that Specialists contribute more to the relational and intellectual capital. To what extent has this capital been appropriated by the Firm? Has Specialists' remuneration been coherent, or is it justifiable to offer them an equity stake in the Firm?

For this purpose, we analyzed each Product by its level of maturity, defined as its sustainability in the Firm without the Specialist. From Figure 3 it can be seen that Products 1, 2 and 3 already existed at the start of the analysis (1996), while Product 4 started to be marketed in 2005, Product 5 in 2008 and Product 6 in 2011. In these initial stages of the life cycle of a Product, when the Specialist is the key person due to his or her role as the originator (relational capital) and specific knowledge (intellectual capital), we considered that the Specialist is already being remunerated through the percentage of profits received from that Product. In this stage it is sufficient to analyze, in light of all the contributions that Specialist is making to the Firm, whether the negotiated percentage is fair. This analysis was carried out along with executives and Shareholders during brainstorming meetings. Figure 4 indicates the percentage of profits to be held by a particular Specialist, depending on his/her relational and intellectual contributions to a Product.

When a Product reaches the maturity stage, in which the Firm originates and performs all the contracts without having to rely on the Specialist, this occurs because the Specialist has already contributed this intangible capital to the Firm. In this case, the Specialist no longer receives a share of the profit from each contract, but it makes sense to allow a continuing reward in the form of an equity stake in the Firm, to allow participation in the value aggregated by this Product to the Firm.

Each Product's stage is a function of the capability of originating and performing new contracts involving the Product without the need for a Specialist. In the previous sections we analyzed the six existing Products and concluded that Products 1,2 and 3 are already in the advanced maturity stage, because they have attained recognized specialization status, and do not need the Specialist's help to perform new contracts. In turn, Product 6 clearly still depends on the relational and intellectual capital of Specialists, while Products 4 and 5 lie between these extremes. In the latter cases (Products 4 and 5), the remuneration was still kept as a percentage of the contracts' profits, exclusively. After all, in these cases care must be taken not to remunerate the same contributions twice.

The policy of granting an equity holding (or an equivalent payment in cash) therefore presupposes that the Specialist has already transferred all the relational/intellectual capital to 
the Firm and can leave without causing any impacts on its cash flow. While the future cash flow of the Product still depends on the Specialist's contribution, it makes more sense to continue remunerating him/her with a percentage of the profit from each contract, recalling that even in situations when a large part of the relational/intellectual capital comes from the Specialist, it is fair for the Firm to have a significant share of the profit, given the risks it runs, as described in section 3 .

To support the decision on the financial arrangement with each Specialist, we used a simplified model, in two steps, that reflects the main concepts detailed in this section:

Step 1: Analysis of the importance of the Specialist regarding introduction of a new Product or conquest of a new client.

This step entails analysis of whether the statements indicated in Figure 4 are true or false, and if true, the weight of the Specialist's contribution to each Product.

The Specialist's contribution to the relational capital

(1) Without him, the client would not have been conquered

(2) He is important to originate new contracts

(3) He knows who to hire for the job execution

The Specialist's contribution to the intellectual capital

(4) He knows the client's and the business' needs

mutch better than any other in the Firm

( 5 ) He dominates the technology/methodology

and the Firm doesn't

(6) He is the warrantor of the project

the share of the Specialist in the contract's profit should be:
Max. Share

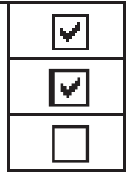

TRUE $10 \%$ TRUE

FALSE

$10 \%$

TRUE

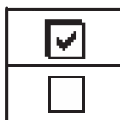

TRUE

Figure 4: Estimating the importance of a Specialist in generating value for a determined Product

Figure 4 is filled in as an example, in the most extreme situation where the Specialist is fundamental and the Firm is only the legal and operational vehicle to perform the contract. In this case, the Specialist might receive up to $60 \%$ of the forecast profit from the contract. This upper limit is to be defined in the brainstorming meetings with Shareholders and Specialists, is the base for defining the maximum weights of each contribution, recalling again that the Firm rather than the Specialists assumes the legal, tax and labor risks. Besides this, the Firm finances the contract and the fixed costs along the way, and also undertakes the risk of default or late payment. 
For situations in the grey area, brainstorming meetings were held to define each Specialist's maximum share of profits, depending on his/her contributions ("maximum share" column in Figure 4), to be clarified through questions such as: Did the Firm provide legal assistance in the contracts covering this Product? Did the Firm provide the team to operationalize the Product? Did the Firm's brand/credibility help to win the Client? Did the relationship of the Firm's officers and its internal team help to originate the contract? Did the Firm also contribute its methods and technology? The greater the number of affirmative answers, the lower the upper limit for that Specialist. In Figure 4, the maximums of $10 \%$ for each contribution are only illustrative. In the real evaluation, each Product has different maximum shares, depending on its history.

In situations in which the conclusion was that a Specialist should have received more for past collaboration, the Shareholders decided to negotiate a settlement, with the aim of keeping those Specialists with the Firm. Shareholders also started to signal to the Specialists that when they contribute their intangible capital to the Firm, they are entitled to an equity stake (or equivalent cash payment), calculated clearly as detailed next in Step 2, to stimulate transfer of knowledge to the Firm.

Step 2: at this point, it is up to the Shareholders to define whether a particular Specialist has already contributed his/her entire intangible capital to the Firm. Step 1 of the analysis helped in this reflection. It is enough here to imagine what the answer would be to the questions in Figure 4 in a new contract involving the Product. If they are all negative, it will indicate that the relational/intellectual capital has already been appropriated by the Firm. Likewise, the percentages of participation considered fair in Step I can serve as a reference regarding the upper bound of shareholding participation to which the Specialist could be entitled in these cases.

In situations where the Firm has already appropriated all the intangible capital, we analyzed each Specialist and each Product where he/she contributed. The equity stake decided by the Shareholders was applied to the value in December 2011 of the Product(s) that each Specialist helped to create /consolidate (obtained as detailed in section 3). We then calculated the percentage that such value represents in the Firm's overall value, reaching the shareholding participation to which each Specialist is entitled.

Table 2 shows the results in percentage terms obtained from the analysis of the participation of the Specialists in the results or profits for each contract, according to the approach described above. 
Table 2: Decision on the Specialists' Share in the Profits from New Contracts, by Product

\begin{tabular}{|l|c|c|c|c|c|c|}
\hline & Product 1 & Product 2 & Product 3 & Product 4 & Product 5 & Product 6 \\
\hline Specialist 1 & 0 & 0 & 0 & 0 & 0 & 0 \\
Specialist 2 & 0 & 0 & 0 & 0 & 0 & 0 \\
Specialist 3 & 0 & 0 & 0 & 0 & 0 & 0 \\
Specialist 4 & 0 & 0 & 0 & $20 \%$ & $20 \%$ & 0 \\
Specialist 5 & 0 & 0 & 0 & $10 \%$ & 0 & 0 \\
Specialist 6 & 0 & 0 & 0 & 0 & $20 \%$ & 0 \\
Specialist 7 & 0 & 0 & 0 & $10 \%$ & 0 & $60 \%$ \\
\hline
\end{tabular}

Note: According to Step 1 of the analysis, the intangible capital related to Products 1, 2 and 3 has already been fully appropriated by the Firm.

It makes sense that the final equity stake in the Firm has to be lower than that originally received as participation in the profits at the time the Product was in its initial stage, since the future of that Product no longer depends on the Specialist's additional time or efforts. Also, other Products to which the particular Specialist did not contribute can become relatively more important in the future value for the Firm. Besides this, the firm might start creating its own technology for that Product, by updating and improving it.

In the case of the mature Products of this Firm, the model only served as a reference for the Shareholders to define, on a case-by-case basis, the possible equity stakes or financial settlements

\section{CONCLUSIONS AND RECOMMENDATIONS}

The article describes, based on a process of valuation of a medium-sized engineering design firm, a method that can be useful to companies that are strongly reliant on human capital and need to appraise their value for prospective merger/acquisition transactions, as well as to structure a system for compensating their key people.

The different dimensions of human capital present in these companies - intellectual, relational and structural - according to the taxonomy observed in studies such as Kristandal \& Bontis (2007) and Lima \& Carmona (2010), helped in the task of ascertaining the contribution of key people to the creation of value for the Firm. Out aim here was to convert that qualitative analysis into monetary values that could be used by the Firm in negotiating of its system of remuneration or equity stakes.

Despite the difficulty of converting the Firm's intangible capabilities into a projection of future cash flows, the executives and shareholders of the Firm in general converged in the formulation of the future scenarios. The process of discussion in the Firm served as an alert 
regarding possible weaknesses and the need to improve the system of information control, to incorporate ongoing record keeping of the costs and revenues per contract/Product, the amounts paid to people as remuneration for each contact, the originally projected revenues and expenses versus the observed cash flows from each contract and type of Product, the rates of success/failure to meet targets and the qualitative contribution of each key person.

The presence of a system to keep track of these aspects and a longer series of historical data would allow more sophisticated analyses of the volatility and risk of each Product, the risk of obsolescence and the options inherent to the Firm, thus allowing a more detailed evaluation of the intangible capital, building on the ideas of authors such as Boutellier \& Karyotis (2010), Deutscher (2005) and Lev (2001).

\section{REFERENCES}

AMRAM, M.; KULATILAKA, N. Real options: managing strategic investment in an uncertain world. Boston: Harvard Business School Press, 1999.

BOUTEILLER, C.; KARYOTIS, C. The evaluation of intangibles: introducing the optional capital. Investment Management and Financial Innovations, v. 7, n. 4, p. 85-92, 2010.

COPELAND, T.; ANTIKAROV, V. Real options: a practitioner's guide. New York: Texere, 2003.

DAMODARAN, A. Equity Risk Premiums (ERP): determinants, estimation and

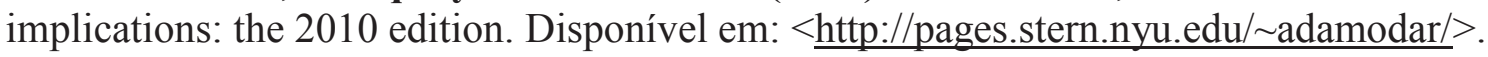
Acesso em: jan. 2011.

DAMODARAN, A. Valuing companies with intangible assets. Set 2009. Disponível em:

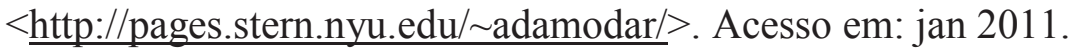

DENG, Z.; LEV, B.; NARIN, F. Science and technology as predictors of stock performance. Financial Analysts Journal, v. 55, n. 3, p. 20-32, maio/jun. 1999.

DEUTSCHER, J. A. Knowledge assets valuation: relevance to innovation process in the companies. 5th Triple Helix Paper ID A056 - May 2005.

HUBBARD, D.W. How to measure anything: finding the value of intangibles in business. New Jersey: John Wiley \& Sons, 2010.

KAYO, E. K. A estrutura de capital e o risco das empresas tangível e intangívelintensivas: uma contribuição ao estudo da valoração de empresas. 2002. 126 f. Tese (Doutorado em Administração) - Faculdade de Economia, Administração e Contabilidade, Universidade de São Paulo, 2002.

KAYO, E. K. et al. Ativos intangíveis, ciclo de vida e criação de valor. Revista de Administração Contemporânea, v. 10, n. 3, p. 73-90, jul./set. 2006. 
KRISTANDAL, G.; BONTIS, N. Constructing a definition for intangibles using the resource based view of the firm. Management Decision, v. 45, n. 9, p. 1510-1524, 2007.

LEV, B. Intangibles: management, measurement, and reporting. Washington: Brookings, 2001.

LEV, B.; MINTZ, S. L. Seeing is believing. CFO Magazine, feb 1999.

LIMA, A. C.; CARMONA, C. U. M. Vetores de criação de valor de ativos intangíveis em empresas de tecnologia da informação e comunicação. In: ENCONTRO DA ASSOCIAÇÃO NACIONAL DE PÓS-GRADUAÇÃO E PESQUISA EM ADMINISTRAÇÃO, 34., 2010, Rio de Janeiro. Anais... Rio de Janeiro: ANPAD. 2010.

LIMA, A.C.; CARMONA, C. U. M. Determinantes da formação do capital intelectual nas empresas produtoras de tecnologia da informação e comunicação. Revista de Administração Mackenzie, v. 12, n. 1, p. 112-138, jan./fev. 2011.

MARISCAL, J.; LEE, R. The valuation of Mexican stocks: an extension of the capital asset pricing model. New York: Goldman Sachs, 1993.

NELSON, W. Applied life data analysis. New York: John Wiley \& Sons, 1982.

REILLY, R. F.; SCHWEIHS, R. P. Valuing intangible assets. New York: McGraw-Hill. 1998.

SULLIVAN, P. Value-driven intellectual capital. New York: John Wiley and Sons, 2000.

SVEIBY, K. E. The new organizational wealth: managing and measuring. San Francisco: Berrett-Koehler. 1997.

TITMAN, S.; MARTIN, J. D. Valuation: the art and science of corporate investment decisions. 2. ed. U.K.: Pearson Education, 2011.

TRIGEORGIS, L. Real options and interactions with financial flexibility. Financial Management, v. 22, n. 3, p. 202-224, Autumn, 1993. 